Article

\title{
Imperceptible Politics: Illegalized Migrants and Their Struggles for Work and Unionization
}

\author{
Holger Wilcke
}

Berlin Institute of Migration and Integration Research, Humboldt University of Berlin, 10099 Berlin, Germany; E-Mail: holger.wilcke@hu-berlin.de

Submitted: 30 November 2017 | Accepted: 6 February 2018 | Published: 29 March 2018

\begin{abstract}
This article argues that illegalized migrants carry the potential for social change not only through their acts of resistance but also in their everyday practices. This is the case despite illegalized migrants being the most disenfranchised subjects produced by the European border regime. In line with Jacques Rancière (1999) these practices can be understood as 'politics'. For Rancière, becoming a political subject requires visibility, while other scholars (Papadopoulos \& Tsianos, 2007; Rygiel, 2011) stress that this is not necessarily the case. They argue that political subjectivity can also be achieved via invisible means; important in this discussion as invisibility is an essential strategy of illegalized migrants. The aim of this article is to resolve this binary and demonstrate, via empirical examples, that the two concepts of visibility and imperceptibility are often intertwined in the messy realities of everyday life. In the first case study, an intervention at the ver.di trade union conference in 2003, analysis reveals that illegalized migrants transformed society in their fight for union membership, but also that their visible campaigning simultaneously comprised strategies of imperceptibility. The second empirical section, which examines the employment stories of illegalized migrants, demonstrates that the everyday practices of illegal work can be understood as 'imperceptible politics'. The discussion demonstrates that despite the exclusionary mechanisms of the existing social order, illegalized migrants are often able to find work. Thus, they routinely undermine the very foundations of the order that produces their exclusions. I argue that this disruption can be analyzed as migrants' 'imperceptible politics', which in turn can be recognized as migrants' transformative power.
\end{abstract}

\section{Keywords}

illegal migration; imperceptible politics; migration; mobile commons; political subjectivity; social change; trade union; Rancière

\section{Issue}

This article is part of the issue "The Transformative Forces of Migration: Refugees and the Re-Configuration of Migration Societies", edited by Ulrike Hamann and Gökçe Yurdakul (Humboldt University of Berlin, Germany).

(C) 2018 by the author; licensee Cogitatio (Lisbon, Portugal). This article is licensed under a Creative Commons Attribution 4.0 International License (CC BY).

\section{Introduction}

I always compare illegalized migrants to superheroes. We are invisible. We work around the clock. We don't get sick. Even when we do get sick, we continue to work. (Illegalized migrant, field notes, 14 October 2015)
In Germany, life as an 'illegal' resident is both legally and socially precarious. ${ }^{1}$ This is defined by lack of access to the job market and social welfare ${ }^{2}$ as well as a constant fear of deportation, which can be felt in even the smallest everyday interactions (De Genova, 2002, p. 438). To work against this, illegalized migrants need-as described in the quotation above-the characteristics of a superhero:

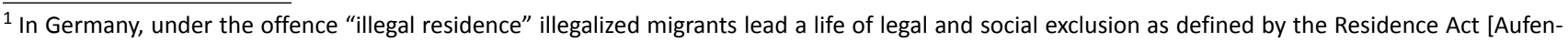
thaltsgesetz, AufenthG].

2 Living without papers in Germany also means no access (or only limited access) to medical care, education and housing (see Hollstein, 2017; Shinozaki, 2015; Wilcke, 2018).
} 
the ability to work even when they are sick and simultaneously the capacity to make themselves invisible.

Most studies of illegalized migrants living in Germany highlight strenuous living conditions and emphasize the social exclusion faced by those without papers (for example, Alt, 2003; Pater, 2005; Wilmes, 2011). In contrast to these studies, I conceive illegalized migrants as political subjects rather than victims (McNevin, 2013, p. 185; Squire, 2017, p. 255). This is not to argue that illegalized migrants have an easy life. On the contrary; pain, anxiety and desperation are often part of their daily experience. However, in this article I have decided to focus on the political practices with which illegalized migrants master the art of living; they are also active subjects who organize their lives under complicated conditions of disenfranchisement. They develop tactics and strategies to deal with their situation and many ultimately find ways to access the labor market, sharing information and knowledge about employers. Illegalized migrants are active participants in society, despite being denied manyalthough not all-civil rights. In their everyday struggles, illegalized migrants take these rights, even if they are not formally entitled (see Schwenken, 2006; Shinozaki, 2015; Wilcke, 2018). The focus of my argument here is that they refuse to passively accept social exclusion.

In this article I contribute to an ongoing debate about political agency of migrants, which takes into account illegalized migrants' everyday struggles and resistance. In this field, Davide Panagia (2006), Anne McNevin (2011) and Walter Nicholls (2013) demonstrate how illegalized migrants in the US and France become political subjects through their claims to equality through hunger strikes, civil disobedience, occupations or rallies. In a similar vein, Peter Nyers and Thomas Nail analyze illegalized migrant's practices in the Sanctuary-City-Movement as 'acts of citizenship' (Nyers, 2010, p. 140ff) or 'migrant cosmopolitanism' (Nail, 2015, p. 188). This body of work is often influenced by Engin Isin's critical thinking on citizenship. For him, acts of citizenship-such as that enacted by Rosa Parks and the Montgomery Bus Boycott, or the hunger strike of Marion Wallace Dunlop (Isin, 2008, p. 18)rupture prevailing perceptions of formal citizenship. Consequently, those people staging acts of citizenship "transform themselves (and others) from subjects into citizens as claimants of rights" (Isin, 2009, p. 368). The examples above are similar in the sense that the political subjectivity of the migrants is constituted though representation and visibility. However, scholars of the 'autonomy of migration' approach, have pointed towards the invisible political practices and interactions of migrants, conceptualizing them as 'mobile commons' (Trimikliniotis, Parsanoglou, \& Tsianos, 2015) or 'imperceptible politics' (Papadopoulos, Stephenson, \& Tsianos, 2008). For the everyday life of illegalized migrants the question of (in)visibility is a crucial one, as Kim Rygiel has elucidated:

If visibility and voice are a key part of the struggles of some irregular migrant group...others have found it necessary to navigate the increasingly restrictive regime of border controls through strategies of disembodiment and invisibility. Here, irregularity becomes a resource to remain outside of the reaches of state authorities. (Rygiel, 2011, p. 157)

I would go further and argue that subjects use both strategies of visibility and imperceptibility; paradoxically this can even occur simultaneously. The aim of this article is to resolve this binary and demonstrate, via empirical examples, that the two concepts are often intertwined in the messy realities of everyday life. Further I examine the extent to which illegalized migrants-as the most disenfranchised subjects produced by the European Schengen border regime-carry the potential for social transformation in their acts of resistance and in their everyday practices. I take the concept of 'social transformation' as my theoretical starting point by drawing on Jacques Rancière's (1999) differentiation between politics and the police. To analyze the migratory strategies of invisibility I confront his ideas with the 'autonomy of migration' perspective already mentioned.

In my first case study, I demonstrate that illegalized migrants transformed society in their fight for union membership, but also reveal that their visible campaigning simultaneously comprised strategies of imperceptibility. In the second empirical section I scrutinize everyday practices of illegal work, examining these in terms of their potential to transform society. To conclude, I discuss the difficulties that arise in capturing the transformative character of imperceptible politics and reflect on the ability of the theoretical concept to grasp the complete repertoire of migrants' political practices.

The research was based on a qualitative design. I interviewed 20 people who live (or lived) undocumented in Germany between 2015 and 2016, two of them activists at Respect, an organization campaigning for the rights of migrant domestic workers. Their stories and descriptions provide the basis for the analysis in this article. In addition, I also drew on participant observation, document analysis, and expert interviews with activists and representatives of various institutions whose work intersects with my first case study. Thus, the two empirical sections on which this article is based comprise of a triangulation of different methods and voices.

\section{Theoretical Perspective: Migration Transforms Society}

Rancière (1999) offers a theoretical frame that links ideas about the constructivist societal order with its exclusionary dynamics. This frame proves fruitful for an analysis of the struggles of illegalized migrants for work and unionization. Essential for Rancière is the fundamental differentiation between the police (la police) and politics (la politique). According to Rancière, the police organizes, administers and protects the distribution of the sensible (partage du sensible), which he regards as the central or- 
der of society and determines the forms of participation (Rancière, 2008, p. 31). Rancière argues that the police "defines the allocation of ways of doing, ways of being, and ways of saying, and sees that those bodies are assigned by name to a particular place and task; it is an order of the visible and the sayable that sees that a particular activity is visible and another is not, that this speech is understood as discourse and another as noise" (Rancière, 1999, p. 29). The police is an inevitable structure, which is part of every hegemonic societal formation. It must promise its members universal validity and equality as well as the claim to represent all. However, the police cannot fulfill this expectation; for Rancière, hegemonic orders always show ruptures and contradictions and are therefore never capable of including everyone.

For Rancière, politics (la politique) is the counterpart to the police, and can be understood as an act of rebellion by those who have no part (1999, p. 14) creating moments in which the contradictions and the constructedness become visible. Rancière argues that it is precisely in these moments that the police order is questioned and renegotiated. According to his analysis, political moments are therefore neither conflicts of interest in the existing order, nor the efforts to create an external, coexisting order-but rather a fundamental dispute about the order itself. These political moments occur for Rancière at the point of conflict where there is a demand for a part by those who have no part (Rancière, 2008, p. 32). This demand-which can be understood as a claim for equality-holds the possibility of social transformation.

A body of 'autonomy of migration' literature proves valuable for determining more precisely how the existing order is expressed in the field of migration. The concept of 'regime' is central here, as it makes it possible to think about the state's dealings with 'illegal migration' by unpacking the concept itself and discussions surrounding it. Rather than assuming the state's dealing with illegal migration is a rigid corset, the autonomy of migration perspective analyzes the materialized regulations themselves as an expression of changeable compromise (Karakayali \& Tsianos, 2007, p. 14). The emphasis on contingency is important here, as it opposes the idea of migration as a something that can be turned on and off depending on the political situation. On the contrary, with this perspective migration can be attributed a certain power that is part of the conflict, and thus it becomes evident that migrants themselves continually challenge the institutional compromises surrounding (illegal) migration (Karakayali, 2008, p. 50). In addition, the concept of 'regime' brings focus to the subjectivities and the subjectivization processes of illegalized migrants. This makes it possible to discuss, in particular, whether political subjectivities are only generated in moments of visibility, or to what extent the political (as Rancière understands it) can also be situated in the process of becoming invisible (Papadopoulos \& Tsianos, 2007, p. 223). This proves valuable because the struggles of illegalized migrants for work and unionization often proceed without obvious breaks and contradictions in the existing order and understanding these struggles therefore requires conceptual expansion. The concept I draw on to make this step is 'imperceptible politics' (Papadopoulos et al., 2008).

Through the imperceptible politics lens, migrant struggles do not necessarily have to become visible to be theorized as politics; they are recognized as politics even if they escape visibility. The existing order is not openly challenged, but rather deceived, cheated, and infiltrated and thus silently and persistently ruptured. For this, invisibility is indispensable: "Becoming imperceptible is the most precise and effective tool migrants employ to oppose the individualizing, quantifying and representational pressures" (Papadopoulos et al., 2008, p. 217). Thereby migrants escape and simultaneously confront what Dimitris Papadopoulos and Vassilis Tsianos call the 'double-R axiom', which describes the stabilization of the nation-state's order through regulation of relations between rights and representation-by becoming imperceptible (Papadopoulos \& Tsianos, 2007). At this point a theoretical antagonism becomes clear. While for Rancière political subjectivities emerge in the moments of disruption in which the invisible and voiceless become visible and audible (Rancière, 1999, p. 30), Papadopoulos et al. argue that imperceptibility is central:

Becoming imperceptible is an immanent act of resistance..... Instead of being perceptible, discernable, identifiable, current migration puts on the agenda a new form of politics and a new formation of active political subjects. (Papadopoulos et al., 2008, pp. 217-218)

In the next section I demonstrate via an empirical case study that these two contradicting approaches can both be understood as migrant strategies. While they may have an ambivalent relationship to each other, both constitute the politics of illegalized practices and also contain within them moments of societal transformation.

\section{Trade Union Representation: Visibility and Invisibility}

In this section, my first empirical case, I demonstrate that even in the most visible struggles for representation migrant strategies of invisibility also occur.

Since 2008, official trade union advisory offices in Germany have supported illegalized migrants. Their existence marks a shift in how trade unions deal with undocumented work and illegal workers. Although it might have been unimaginable 20 years ago for unions to support people without a residency permit (and thus without a work permit), this perspective has now largely shiftedeven if there are still contradictory positions within the trade unions. How did this shift occur? This article argues that the societal shift cannot be conceived without migrant and anti-racist struggles, which claimed rights for illegalized migrants and demanded these in a perceptible manner. 
The Gesellschaft für Legalisierung (GfL), ${ }^{3}$ which was formed in 2003 as an alliance of different political groups and organizations, played a decisive role in this process. When the alliance formed, their focus was on the rights of illegalized migrants and their goal was both simple and radical: they demanded a society in which migration is not judged in terms of economic interests, in which life is not organized hierarchically along racist lines, and where freedom of movement is possible, disenfranchisement and illegalization are impossible (see GfL, 2003). Against this background, the alliance launched a legalization tour in 2003, in which different forms and effects of illegalization were made visible and modes of resistance were emphasized. In autumn 2003, during this tour, the GfL intervened in the federal conference of the trade union ver.di in Berlin, demanding that people without residency status and work permits be included as members.

The need for illegalized migrants to be able to unionize was communicated to the conference participants in various ways. One of the more creative examples was an audio recording that could be heard coming from large suitcases. In this installation, the voices of illegalized migrant workers could be heard making demands for political and social rights. Pamphlets were also distributed to conference participants, which called for a trade union for all workers, regardless of their legal status. In parallel, in the foyer of the International Congress Center (ICC) in Berlin, negotiations were being carried out to make the political goals of the alliance public. The negotiations were successful, but they were agreed on the condition that no one without papers would speak (Respect, 2003). The Respect activist, who went on stage remembers the situation as follows:

We wanted to do something artistic, but also something to provoke the audience, so that people notice that we're here. And that's why we were loud. Then someone came over and said: 'Enough now. We'll give you 10 minutes [on stage]'. I was right there when someone asked: 'Do you want to go in?' And I said 'Yes'. But I didn't expect it to be so packed, that so many people would be inside.... also didn't know that Angela Merkel was inside. I only realized that later. (interview, Respect Activist A)

Part of the success of this intervention is illustrated in the quotation, namely that the activists themselves did not expect to be able to gain the right to speak, nor that their demands would have such positive resonance with the participants. The speech of the activist-who herself lived in Germany for a long time without papers-are detailed in the conference minutes:

Thank you for the opportunity to speak here. I ask you to listen to us. Please hear us. There are many of us, and we already live among you. We work in this coun- try. Since we already work here, we also have rights. We hope to find support among the delegates here; we hope they will make our issues their cause. We also want to receive our salary regularly at the end of each month. We don't want to be sexually abused during work. We don't want to be vastly underpaid for our work anymore. Finally, we just want to work normally, with dignity, just like all of you do. (Applause). We are workers. We need the support of the trade union. We need someone who will carry our voice to the outside. That's why we want to be members of the union (Shouts of bravo. Applause). (ver.di, 2003)

As noted in the minutes, the speech was very popular with the conference participants and can be regarded as a political moment (Rancière, 1999). The speech provided decisive impetus for further discussions within the union and was evaluated as a success by the activists. But how can the intervention, specifically the speech, be evaluated in tension between visible and invisible politics? Firstly, it is necessary to clarify the existing social order of the trade union organization and whether the activists can be understood as those who have no part.

The literature on German trade unions reveals that unions historically had restrictive (and even hostile) positions with regards to migration (see Ağtaş, Amler, \& Sauviat, 2008; Bojadžijev, 2012; Trede, 2015). More recently, the situation has become ambivalent. During the crisis of the trade unions (broadly characterized by declining membership figures, lower revenues and general loss of meaning) there were attempts to approach potential new members. However, while new members were needed, projects that focused on including illegalized migrants remained marginal, best illustrated by the lack of funding for a legalization campaign within the metal workers union in Germany ${ }^{4}$ (see Ağtaş et al., 2008) and the decline of the European Migrant Workers Union (see Mitrović, 2009). This demonstrates that there remains a (deeply entrenched) hegemonic understanding that regards illegal work as the decisive factor in decreasing wages.

Accordingly, in Rancière's terms, illegalized workers can be understood as those who have no part. In 2003, when the GfL staged its intervention at ver.di, none of the official members were without residency status or work permit. The hegemonic positions regarding illegalized migrants, as described above, determined the existing order-to the extent that membership without residency status or work permit would have been unthinkable. Therefore, the moment at which the activist walked onto the conference stage and made her demand for membership within the union can be understood as politics in Rancière's sense. By encouraging the audience not only to "listen" to her, but to "us" as illegalized migrants, the activist made the existing order visible and created a moment in which the boundaries between participation and exclusion, language and noise, visibility

\footnotetext{
${ }^{3}$ Which can be translated as 'Society for Legalization'.

${ }^{4}$ IG Metall.
} 
and invisibility-were questioned. The speech-in which union membership is visibly claimed as illegalized migrants part-thus provoked a fundamental discussion about social order itself.

The question arises, whether this speech can be seen as the starting point for a fundamental change in the existing order of the trade union organization, or whether the existing order is merely reaffirmed. A political moment in which the existing order is questioned does not necessarily produce a new order in which there is a different distribution of the sensible (Rancière, 1999, pp. 41-42). The GfL disbanded shortly after the tour described here, as the group did not manage to unite the different perspectives nor create one productive joint platform (John, Panagiotidis, \& Tsianos, 2008, p. 29). In order to further pursue the question of (in)visible politics within this case study, it is useful to consider Respect ${ }^{5}-$ one of the political groups which was part of the GfL.

Respect was founded in 1999 with the goal of organizing women in paid housework. Its membership comprised women of different origins and different residency status' - many of them previously active in migrant organizations, counseling centers, feminist contexts and support groups (Respect, 2012). Respect was decisive not only for the GfL activities at the federal conference but also for the more specific development within ver.di. Respect activists were already holding talks with ver.di conference participants about the potentials and challenges of cooperation and integration of illegalized migrants into the trade union. This resulted in personal contacts, which formed the basis for further cooperation (see Respect Activist B, 2005, p. 56). In the subsequent collaboration between Respect and ver.di the main focus was to explore the possibilities of illegalized migrants becoming members and thus to implement the main goals of Respect. With overwhelmingly positive reactions from the conference, concrete results came relatively quickly:

Then two or three months later we had the opportunity to become members. It was incredibly fast. ver.di wanted new members, of course. And we said, if it's alright with you, then we'll become members. (interview with Respect Activist $A$ )

This marked the first major change in union regulations. The official recognition of illegalized migrants as trade union members represented a novelty in Germany. In addition, Respect succeeded in combating inter-union resistance and bureaucratic hurdles to establish an official trade union advisory office for illegalized workers. The successful fight for membership, legal protection and an advisory body (which not only informs and advises illegalized migrants, but also institutionalizes the opening up of the trade union) in sum mark a changed perspective on illegalized migrants. This opening continues to be highly controversial within the trade unions, as many still believe the unionization of workers without residency permits and work permits is an affront against the traditional values and politics of the union. However, in the struggle described here, illegalized migrants fought for $a$ part, which was not foreseen by the existing order of the unions. Therefore, the speech described here and the process that followed can be described as politics.

Nevertheless, with Rancière's understanding of political subjectivation it is not possible to grasp all of the political dimensions of the struggles for unionization. Thus far the discussion of a concrete case demonstrates that contradictions arise. Firstly, there were no illegalized migrants present at the ver.di conference intervention, at least not physically. Therefore, those without a part were not themselves on site to make the demands for a part. Their presence and visibility could only be produced by an audio installation:

We have set up 'sacs tati', they're big suitcases from which you can hear recorded voices. They are the voices of people without papers who are demanding social and political rights. It is only with the suitcases that they can claim the space, which they did not want to take directly on that day for fear for imminent criminalization. (Respect, 2003)

The quotation addresses the ambivalence that is constantly present for the illegalized migrants in their struggle for visibility. The absence of residency permits is a constant threat, so that even before the intervention took place, unwanted control measures, which are relatively likely during an intervention of this sort, were preempted. Thus, the aim was that visibility-or more specifically audibility-would be established without physical presence. In the speech of the Respect activist there was a similar aim; she talks in plural of 'we' the illegalized, without being illegalized herself. She speaks as a representative for illegalized workers, as a former illegalized migrant who in the meantime has successfully secured residency status in Germany. Furthermore, as became obvious in the negotiations about the right to speak with ver.di representatives, the union insisted that no illegalized migrant would be allowed to speak as this could be considered a provocation for both the legislative and for many of the delegates (Respect, 2003). While the activist making the speech was not an illegalized migrant when she stood on stage, as a former illegalized migrant she demanded recognition for those without a part, and therefore created visibility for illegalized migrants. The situation was paradoxical precisely because they themselves were not present.

The paradox can also be found in the second example, related to the demand of union membership itself. One of the key objectives of the unionization was representation by a socially relevant institution.

It was important to be with ver.di because it's recognized as official. We wanted to say there are ille-

\footnotetext{
${ }^{5}$ Respect is a political group in Berlin, which is organized in the European network of migrant domestic workers also called Respect.
} 
galized migrants at ver.di, so it becomes more confrontational for society. We entered without permission. And if ver.di is part of the state, then we also belong here. (interview with Respect Activist A)

Becoming visible through the organization and membership in a German union and able to carry the concerns of illegalized workers into wider society simultaneously provides invisibility on the individual level-and here the ambivalence becomes obvious. How can this apparent contradiction be explained, which Respect Activist A conveys as a fundamental conflict:

The [illegalized] migrants are always afraid and that was our conflict. How can we do something? ver.di gave us the opportunity to do something different without fear...the right to unionize. We have the right to be here. And we have the right to use the lawyers. (interview with Respect Activist A)

This dual function of visible-invisible has the advantage of being legally represented by ver.di, and thus the ability to claim and enforce labor rights, while simultaneously providing the safety of invisibility, which can be of vital importance for life in illegality (see Rygiel, 2011, p. 157).

In Rancière's understanding, the political, which lies within the struggles described here, emerges in the moments in which the existing order is visibly challenged. The question arises as to how far invisibility, remaining invisible, or becoming invisible can also be understood as political-or whether societal change is only conceivable with a visible political subject. Theoretically this question has already been discussed above. To answer this question on an empirical level, in the next section I will focus on everyday resistance practices and struggles of illegalized migrants.

\section{Everyday Struggles for Work: Inevitable Invisibility}

In this section, my second empirical case, I analyze illegalized migrants' everyday practices of working and sharing specific knowledge. This empirical-theoretical investigation analyses whether, and in how far, illegalized migrants change society, even when they remain imperceptible.

I have to be invisible. If I attract any attention, the consequences could be disastrous. In the end they will put me on a plane and send me back. (interview with Andrew)

Andrew ${ }^{6}$ gets to the crux of the matter. The ever-present danger of deportation-which De Genova (2002, p. 438) understands as deportability-is embedded in the everyday lives of illegalized migrants. Invisibility is the defining feature of illegality, and at the same time, a prerequisite for life in as illegal. Invisibility does not mean that bodies are imperceptible in everyday life. On the contrary, they live and move about in the city-center, travel on the train, or like Isaac, ${ }^{7}$ work in the centers of political power:

I worked for a catering business. And once I even had to work at the Bundestag....It wasn't a problem. I went there with my friend's passport. You have to be sure of what you are doing. (interview with Isaac)

And yet, Isaac becomes an inconspicuous caterer with his friend's passport and with the self-assurance and certainty that the physical differences between him and the passport holder will not be noticed during the check. In the performance, the process of "being everyone" and "becoming imperceptible" take place (Papadopoulos \& Tsianos, 2007, p. 228).

Carrying and using the borrowed ID documents is a cunning strategy, in which Isaac refuses to accept the label "illegal migrant" and is able to earn money. Ekuwa, ${ }^{8}$ who lived in Germany for several years without papers, pursued a different strategy of invisibility.

I knew the police wouldn't come to a private home. They raid hotels or companies, but I have never heard of private homes. Although I knew the family wouldn't do anything. (interview with Ekuwa)

From the outset Ekuwa aimed for employment in paid housework, as she knew these jobs would be less likely to be subject of workplace controls. In addition, she trusted the family, as two of her friends had already worked there and reported "positive experiences". Key to Ekuwa's strategy of invisibility is her prior knowledge. On the one hand is her knowledge that property rights in Germany are taken so seriously that raids-for example those carried out by customs authorities on illegal employment-are very rare compared to raids in other workplaces such as building sites. On the other hand is her knowledge of trustworthy employers who, like in this case, pay well and do not run the risk of telling authorities about their employees lack of residency status. This 'situated knowledge' (Haraway, 1995) is generated by experiences and the subsequent exchange and sharing of these experiences with others. It is a specific knowledge, which is produced by the individual position of illegalized migrants in relation to the societal conditions they find. As 'mobile commons' this knowledge offers basic resources for living (and surviving) and everyday participation in society (Papadopoulos \& Tsianos, 2013, p. 190). These mobile commons circulate within transnational social networks and are thereby continually updated and expanded. They are invisible goods that belong to no one and which cannot be controlled by anyone. Accordingly,

\footnotetext{
${ }^{6}$ Name altered.

7 Name altered.

${ }^{8}$ Name altered.
} 
the migrant-situated knowledge is not only a product of reoccurring experiences of migrant life, but also the prerequisite for everyday practices that allow (and produce) alternative forms of life (Bojadžijev, 2012, p. 147; Trimikliniotis et al., 2015, p. 1040). In this sense mobile commons facilitate life in illegality, for example when people are able to avoid police controls of the labor market, or evade particularly exploitative working conditions such as unreliable pay or unpredictable employers.

In sum, mobile commons facilitate work in illegality. This can be understood as politics because there is no designated place for illegalized migrants in the existing order. Yet illegalized migrants such as Ekuwa or Isaac take their right to work-which is denied by the police order-via different strategies of invisibility. Fundamentally, they demand a part, which was not intended for them. Importantly, these actions are a form of politics that do not need to be intentional; the illegalized do not organize a conscious and collective struggle for their share. Rather, the political is generated from the fact that there is no choice; they must work ("You just have to work", interview with John ${ }^{9}$ ) to earn money ("You need money, life in Germany is expensive", interview with Andrew). And yet, as those who have no part, they take their part by working in an imperceptible manner. In this sense their work can be understood as invisible politics-despite ambivalent employment conditions and moments of exploitation and disenfranchisement.

This second empirical section demonstrates that both illegalized migrants working without a permit and the sharing of migrant-situated knowledge can be understood as imperceptible politics. Over and above this analysis, on a theoretical level, this means that the everyday practices of illegalized migrants have transformative potential. However, precisely because of the imperceptibility of those practices, it is difficult to conceive the transformative character on an empirical level. The concrete transformation on the ground cannot be captured, until the practices become visible. In the next section I scrutinize this tension by means of an example from the past.

\section{The Transformative Power of Imperceptible Politics}

How can the transformative potential of illegalized migrants working without a permit be proven beyond an abstract theoretical discussion? This is a difficult task due to the inherent invisibility of the illegalized workers. As argued above, the politics of invisibility emerge in the deception, ambiguity and infiltration of the existing order, rather than in open confrontation. The argument that the politics are socially transformative will be demonstrated with an example from 2001. At the time, more than 200 illegal domestic helpers from East European countries, which were not yet part of the EU, were deported. There was a large-scale raid carried out by the federal police in Frankfurt am Main, in which over
350 homes were searched (see Bojadžijev, Karakayali, \& Tsianos, 2003). A journalist was amongst those who were involved, as he had employed a care-worker without papers from Slovakia to care for his father in law. The careworker faced deportation as part of the raid. The journalist made his loss public and thus paved the way for a public debate about the necessity of migrant care-workers in private homes. Der Spiegel ${ }^{10}$ described the lack of German care workers (with work permits) and their relatively high cost as a main reason why Polish or Czech women are often the only option for families who want to keep their elderly relatives at home (Hielscher, 2001).

The Eastern European migrants had proven indispensable as care workers. Consequently, the ministry of labor reacted by amending the regulations and, under certain conditions, permitting migrants from five selected EU countries to work in households that required care workers. It is interesting to note that migration processes had already somewhat changed the societal terrain, even before the political attempt to regulate migration by securing migrant workers with jobs protected by social insurance (see Bojadžijev et al., 2003; Karakayali, 2007). This makes it clear that illegalized migrants take their place in society by working and changing their everyday practices. Yet they do not demand their part openly; they appropriate it in clandestine, imperceptible ways. The fact that the politics are imperceptible is also shown in this example. It was only through the raid, the deportations, and the subsequent public discussions that the transformation of society occurred. It was only through the work of illegalized care workers that this process became visible and empirically tangible.

\section{Conclusions}

As demonstrated in the previous sections, invisibility is a fundamental strategy in the everyday life of illegalized migrants. The politics of invisibility can be seen even in the struggles for visibility and representation, as described in the campaigns for union membership. In the demand for union organization, as demanded by the GfL and Respect, this can be analyzed as a doublestrategy; the presence of illegalized workers as a group (their rights and social exclusions) are made more visible, without risking the potential deportation and residency controls of individual illegalized migrants. While this struggle for membership might be criticized from the perspective of imperceptible politics as outdated politics of representation, which are easily absorbable by the existing order, Rancière's idea of political subjectivization would omit the importance of invisibility. Both concepts-perceptible and imperceptible politicshelp to understand illegalized migrant as political subjects. However, it must be noted that neither perspective is capable of grasping the full spectrum of political migrant practices, as the analysis of the empirical cases

\footnotetext{
${ }^{9}$ Name altered.

${ }^{10}$ A German weekly news magazine.
} 
in this article demonstrates. The concepts need to be combined on an empirical and theoretical level (see Nyers, 2015; Schweitzer, 2017). While Rancière's differentiation between police and politics might be useful to analyze social transformation, his conception of political subjectivization is limited to the process of becoming visible. This needs to be reconsidered. Becoming imperceptible is-as discussed theoretically-a crucial aspect of the politics of illegalized migrants, which can be confirmed on an empirical basis.

Isaac works as a caterer for a company that does not know about his lack of residency papers. For this work he uses a friend's identity. With the help of his friend's passport and his knowledge about the rules that dominate society he is able to overcome all the barriers, which usually prevent illegalized workers the formal entry into work. Ekuwa has deliberately chosen work as a housekeeper in order to minimize the risk of official controls. The avoidance of certain places and employment that are heavily controlled, which illegalized workers expect pose an increased danger for them, is a further strategy of invisibility. And it is precisely deportability, which makes imperceptibility essential for life in illegality. None of the strategies-whether a focus on specific employers or borrowing identity documents-have the aim of visibly calling into question the exclusion mechanisms and respective modes of disenfranchisement, nor do the strategies demand participation for the workers. The aim of these strategies is for illegalized migrants to become imperceptible, to enable participation in society. This is precisely where imperceptibility becomes political; the social part that is not foreseen for illegalized migrants in the police order is not demanded at the moment of their visibility. Rather, the social recognition is appropriated performatively in everyday life. Illegalized workers work, despite the existing order and its exclusionary mechanisms. They are active, and participate in society, and simply take those rights, which are not foreseen for them. As demonstrated by the example of the illegalized care workers who were deported after police raids in 2001, social order is transformed in imperceptible ways by illegal work. The care workers made themselves indispensable through their invisible work, which became visible through the deportations and then expressed itself in the changes in law.

Illegalized migrants, as the most disenfranchised subjects that the European border regime produces, transform society. They develop diverse strategies to deal with the conditions they find and to participate in social processes from which they are formally excluded. Thus, they routinely undermine the very foundation of the social order that produces their exclusions. This is the transformative power of illegalized migrants' imperceptible politics.

\section{Acknowledgements}

This work was supported by the Rosa Luxemburg Foundation, Germany.

\section{Conflict of Interests}

The author declares no conflict of interests.

\section{References}

Ağtaş, Ö., Amler, B., \& Sauviat, L. (2008). Between organising and exclusion: Trade union strategies and undocumented migrant workers. In: Heinrich-BöllStiftung (Ed.), Leben in der Illegalität (pp. 72-78). Berlin: Heinrich-Böll-Stiftung.

Alt, J. (2003). Leben in der Schattenwelt. Karlsruhe: Loeper. Bojadžijev, M. (2012). Die windige Internationale. Rassismus und Kämpfe der Migration. Münster: Westfälisches Dampfboot.

Bojadžijev, M., Karakayali, S., \& Tsianos, V. (2003). Das Rätsel der Ankunft. Von Lagern und Gespenstern. Arbeit und Migration. Kurswechsel, 3, 39-52.

De Genova, N. (2002). Migrant 'illegality' and deportability in everyday life. Annual Review of Anthropology, 31, 419-447.

Gesellschaft für Legalisierung (2003). Aktionstag 24.10. Retrieved from http://www.rechtauflegalisierung. de/aktuell/aktionstag/strasse_b.html

Haraway, D. (1995). Die Neuerfindung der Natur. Primaten, Cyborgs und Frauen. Frankfurt am Main and New York: Campus.

Hielscher, A. (2001). Notstand. Green Card für Polinnen? Retrieved from http://www.spiegel.de/spiegel/ print/d-20073715.html

Hollstein, T. (2017). Illegale Migration und transnationale Lebensbewältigung. Wiesbaden: Springer.

Isin, E. (2008). Theorizing acts of citizenship. In E. Isin \& G. Nielsen (Eds.), Acts of citizenship (pp. 15-43). London: Palgrave Macmillan.

Isin, E. (2009). Citizenship in flux. The figure of the activist citizen. Subjectivity, 29(1), 367-388.

John, F., Panagiotidis, E., \& Tsianos, V. (2008). Kick it like Okocha-cha. Von der Gesellschaft für Legalisierung und den Fallstricken der Repräsentation. Fantômas, 13, 28-30.

Karakayali, J. (2007). Mit und ohne Papiere. Migrantinnen aus Osteuropa als Haushaltshilfen in Haushalten mit Pflegebedürftigen. In B. Figatowski, K. Gabriel, \& M. Meyer (Eds.), The making of migration. Repräsentationen, Erfahrungen, Analysen (pp. 48-57). Münster: Westfälisches Dampfboot.

Karakayali, S. (2008). Gespenster der Migration. Zur Genealogie illegaler Einwanderung in der Bundesrepublik Deutschland. Bielefeld: Transcript.

Karakayali, S., \& Tsianos, V. (2007): Movements that matter. In Forschungsgruppe TRANSIT MIGRATION (Ed.), Turbulente Ränder. Neue Perspektiven auf Migration an den Grenzen Europas (pp. 7-22). Bielefeld: Transcript.

McNevin, A. (2011). Contesting citizenship. Irregular migrants and new frontiers of the political. New York: Columbia University Press. 
McNevin, A. (2013). Ambivalence and citizenship: Theorising the political claims of irregular migrants. Millennium: Journal of International Studies, 41(2), 182-200.

Mitrović, E. (2009). Qualitative Befunde zur Lebenssituation von Menschen ohne gültige Aufenthaltspapiere in Hamburg. In Diakonie Hamburg (Ed.), Leben ohne Papiere (pp. 134-213). Hamburg: Diakonie.

Nail, T. (2015). Migrant cosmopolitanism. Public Affairs Quarterly, 29(2), 187-200.

Nicholls, W. (2013). Making undocumented immigrants into a legitimate political subject: Theoretical observations from the United States and France. Theory, Culture \& Society, 30(3), 82-107.

Nyers, P. (2010). No one is illegal between city and nation. Studies in Social Justice, 4(2), 127-143.

Nyers, P. (2015). Migrant citizenships and autonomous mobilities. Migration, Mobility \& Displacement, 1(1), 23-39.

Panagia, D. (2006). The poetics of political thinking. Durham: Duke University Press.

Papadopoulos, D., Stephenson, N., \& Tsianos, V. (2008). Escape routes. London: Pluto Press.

Papadopoulos, D., \& Tsianos, V. (2007). The autonomy of migration: The animals of undocumented mobility. In A. Hickey-Mood \& P. Malins (Eds.), Deleuzian encounters. Studies in contemporary social issues (pp. 223-235). New York: Palgrave.

Papadopoulos, D., \& Tsianos, V. (2013). After citizenship: Autonomy of migration, organisational ontology and mobile commons. Citizenship Studies, 17(2), 178-196.

Pater, S. (2005). Menschen ohne Papiere. Düsseldorf: Retap.

Rancière, J. (1999). Disagreement: Politics and philosophy. Minneapolis: University of Minnesota Press.

Rancière, J. (2008). Zehn Thesen zur Politik. Berlin: Diaphanes.

Respect. (2003). Represented by Verdi. Gewerkschaften und die KollegInnen ohne Papiere. Retrieved from http://www.rechtauflegalisierung.de/text/verdi3.html

Respect. (2012). Austritt aus dem AK undokumentierte Arbeit in ver.di. Retrieved from http://www. respectberlin.org/wordpress/2012/11/austritt-ausdem-ak-undokumentierte-arbeit-in-ver-di

Respect Activist B. (2005). 'Wir wollen was uns zusteht'. Migrantische Hausarbeit und der Kampf um gewerkschaftliche Rechte. In Interface (Ed.), WiderstandsBewegungen. Antirassismus zwischen Alltag und Aktion (pp. 55-60) Berlin and Hamburg: Assoziation $\mathrm{A}$.

Rygiel, K. (2011). Governing borderzones of mobility through e-borders: The politics of embodied mobility. In V. Squire (Ed.), The contested politics of mobility. Borderzones and irregularity (pp. 143-168). London: Routledge.

Schweitzer, R. (2017). Integration against the state: Irregular migrants' agency between deportation and regularisation in the United Kingdom. Politics, 37(3), 317-331.

Schwenken, H. (2006). Rechtlos, aber nicht ohne Stimme. Bielefeld: Transcript.

Shinozaki, K. (2015). Migrant citizenship from below: Family, domestic work and social activism in irregular migration. New York: Palgrave.

Squire, V. (2017). Unauthorised migration beyond structure/agency? Acts, interventions, effects. Politics, 37(3), 253-272.

Trede, O. (2015). Zwischen Misstrauen, Regulation und Integration. Paderborn: Schöningh.

Trimikliniotis, N., Parsanoglou, D., \& Tsianos, V. (2015). Mobile commons and/in precarious spaces: Mapping migrant struggles and social resistance. Critical Sociology, 42(7), 1035-1049.

ver.di. (2003). Kongressjahr 2003. Tagesprotokoll Freitag - 24.10.2003, Teil I, 9.09 - 10.53 Uhr. Retrieved from http://kongressjahr2003.verdi.de/bundeskongress/ protokolle/1024-1

Wilcke, H. (2018). Illegal und unsichtbar? Papierlose Migrant*innen als politische Subjekte. Bielefeld: Transcript.

Wilmes, M. (2011). Regular migration and foggy organisational structures. In M. Bommes \& G. Sciortino (Eds.), Foggy social structures. Irregular migration, European labour markets and the welfare state (pp. 117-140). Amsterdam: Amsterdam University Press.

\section{About the Author}

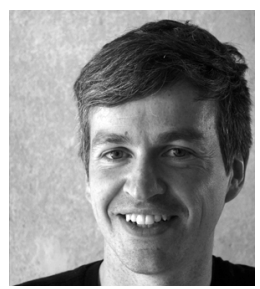

Holger Wilcke holds a PhD in Geography from the Humboldt University of Berlin. He is a Research Associate with the Berlin Institute for Integration and Migration Research (BIM) at Humboldt University of Berlin. His work focuses on migration and social movements as well as the politics of migratory struggles. He is a member of the Network for Critical Border and Migration Regime Research (kritnet). 